\title{
Nonlinear anisotropic diffusion techniques for seismic signal enhancing - Carpathian Foredeep study
}

\author{
Mateusz Zaręba*, and Tomasz Danek \\ AGH University of Science and Technology, Department of Geoinformatics and Applied Computer \\ Science, Cracow, Poland
}

\begin{abstract}
The use of nonlinear anisotropic diffusion algorithm for advanced seismic signal processing in the complicated geological region of Carpathian Foredeep was examined. This technique allows for an improvement of seismic data quality and for more accurate interpretation by the recovery of a significant amount of structural information in the form of a correlating seismic reflections and by preserving true DHI indicators. It also allows searching for more subtle geological structures. Anisotropic diffusion is an iterative image processing algorithm that removes noise by modifying the data by solving partial differential equations. Moreover, it can reduce image noise without blurring the edges between regions of different chrominance or brightness. This filter preserves edges, lines, or other features relevant to the seismic structural and stratigraphic interpretation. The algorithm also enables noise reduction without removing significant information from a seismic section even for high dips values. For a better estimation of anisotropic diffusion structure tensor, the parameterization is done using the depth field and the calculations in the two-way travel time field. The presented research shows the results of using an anisotropic diffusion algorithm for post-stack and migration processing of seismic 3D data collected in Carpathian reservoir rocks of southern Poland.
\end{abstract}

Keywords: signal processing, seismic, anisotropic diffusion, Carpathian Foredeep, nonlinear algorithm, seismic interpretation

\section{Introduction}

Obtaining more accurate and detailed images of the subsurface based on seismic surveys is one of the core functions of seismic processing, especially when data is acquired in the region of complicated geology. Such conditions require more specific processing techniques to obtain an image that can be properly interpreted. The Carpathian Foredeep is undoubtedly an example of a region where complex geology is a challenge for seismic investigations. On seismic sections from this region, plenty of artefacts that are generated by different phenomena must be eliminated before a distinct reflection from particular geological

\footnotetext{
*Corresponding author: mattzareba@gmail.com
} 
structures can be observed. The sedimentary profile of the Carpathian Foredeep is very specific and highly variable due to the mosaic type of flysch tectonic observed in seismic images [1]. In recent years, the understanding of the stratigraphy and lithology of The Carpathian Foredeep has increased, thanks to geophysical surveys and newly developed seismic and well-logging techniques [2]. Many studies have been done in this part of Poland because of its reservoir potential [3]. Seismic observations allowed the discovery of oil and gas reservoirs in the Carpathian Mountains and their Foredeep; however, despite many studies and progress in seismic techniques, proper processing and interpretation of seismic data is still a challenge. The importance of developing processing techniques, guided on improving the seismic image, has been widely discuses in many papers $[4,5,6]$. According to a recent geological modelling study of the inner structure of autochthonous Miocene deposits, a new seismic approach is essential for the recognition and proper localization of unconventional reservoirs in this region [7]. Another recent example of the critical importance of processing in The Carpathian Foredeep seismic interpretation was shown by Kubociński [8]. He presented new techniques of three-dimensional, angle domain pre-stack depth migration results for the discussed area. The importance of flysch rocks effects is studied in detail in [1]. These challenges of high values of dips and latterly changing velocities constitute an environment where poor signal quality, which degrades with depth, is not common and where the new techniques of seismic processing are needed. This paper is focused on one technique, namely non-linear anisotropic diffusion, which has been known and used for several years in digital image processing. Recently, the first application of this technique in the Polish Carpathian Foredeep seismic surveys was presented by Zaręba [9]. This paper presents the broadening results of the application of this technique in seismic data processing.

\section{Anisotropic diffusion filtering}

It has been observed that using filters based on anisotropic diffusion can simplify the digital image by filtering out signals that do not provide relevant information [10]. The most important advantage of the anisotropic diffusion is preserving the edges of the smooth structures [11]. A similar procedure can be applied in the case of a seismic signal defined as collection of samples gather in sets of particular traces. Anisotropic diffusion filtering can simplify a seismic section by reducing noise, which provides better quality horizons.

In case of seismic data, the role of pixels with high gradient magnitude can be replaced by amplitude changes in the time-space domain window. Usually a common depth point domain as a time-space representation is used. Enhancing seismic signatures can help in obtaining better sections for structural interpretation.

Anisotropic diffusion can improve fault interpretation in 3D seismic surveys and provides dip and fault inclinations and azimuth values (e.g., [9]). The second advantage of this algorithm is complex de-noising of seismic data while preventing the layer's borders and enhancing the signal as demonstrated by Baddari et al. [12]. Additionally, processing using this type of algorithm can improve the final results of depth migration. It is due to the fact that the velocity model for depth migration is created without perfect knowledge of the real position of structures. This procedure makes it possible to obtain the correct depth image of subsurface structures, which can be used for further stratigraphic interpretation (e.g., [13]). As a result, the obtained seismic section, after time migration with an enhanced signal to noise ratio and depth to time conversion, is more accurate.

A typical algorithm for anisotropy diffusion filtering is as follows (e.g., [14, 15]):

$$
\frac{\partial U}{\partial t}=\operatorname{div}(c \nabla U)
$$


where $\mathrm{c}$ is a diffusion coefficient for filtering and $\mathrm{U}$ is the intensity function of the data.

Equation 1 shows typical convolution with Gaussian kernel. It helps preserve the edges of the image and deals with fuzziness. However, to prevent edges of a 3D structure, the diffusion coefficient from Equation 1 has to be replaced with tensors:

$$
\frac{\partial U}{\partial t}=\operatorname{div}(D \nabla U)
$$

Diffusion coefficients are stored in Matrix D. It is simply the central difference disperse equation with a Neumann boundary condition. Weickert [16] proposed a use of structure tensor $\mathrm{J}_{\rho}$ as powerful tool for examining coherence structures:

$$
J_{\rho}\left(\nabla U_{\sigma}\right)=K_{\rho}^{*}\left(\nabla U_{\sigma} \otimes \nabla U_{\sigma}\right)
$$

where $\mathrm{K}_{\rho}$ is a Gaussian kernel, $U_{\sigma}$ is a Gaussian-smoothed version of the image, $\rho$ is a scale factor, and $\sigma$ is a noise scale.

Gradient vector $\mathbf{v}_{1}$ and the structure orientation $\mathbf{v}_{2}$, at scale $\rho$ are represented by eigenvectors of $\mathrm{J}_{\rho}$. To be able to use Equation 3 for $3 \mathrm{D}$ seismic needs, the structure tensor $\mathrm{J}_{\rho}$ becomes:

$$
J_{\rho}\left(\nabla U_{\sigma}\right)=K_{\rho}^{*}\left(\begin{array}{lll}
\left(\frac{\partial U_{\sigma}}{\partial x}\right)^{2} & \frac{\partial U_{\sigma}}{\partial x} \frac{\partial U_{\sigma}}{\partial y} & \frac{\partial U_{\sigma}}{\partial x} \frac{\partial U_{\sigma}}{\partial z} \\
\frac{\partial U_{\sigma}}{\partial x} \frac{\partial U_{\sigma}}{\partial y} & \left(\frac{\partial U_{\sigma}}{\partial y}\right)^{2} & \frac{\partial U_{\sigma}}{\partial y} \frac{\partial U_{\sigma}}{\partial z} \\
\frac{\partial U_{\sigma}}{\partial x} \frac{\partial U_{\sigma}}{\partial z} & \frac{\partial U_{\sigma}}{\partial y} \frac{\partial U_{\sigma}}{\partial z} & \left(\frac{\partial U_{\sigma}}{\partial z}\right)^{2}
\end{array}\right)
$$

To be able to use Equation 4 in the algorithm, the iterative form is needed:

$$
\begin{gathered}
U^{n+1}=U^{n}+\Delta x \Delta y \Delta z\left\{\frac{\partial}{\partial x}\left(D_{11}^{n} U_{x}^{n}\right)+\frac{\partial}{\partial x}\left(D_{12}^{n} U_{y}^{n}\right)+\right. \\
\frac{\partial}{\partial x}\left(D_{13}^{n} U_{z}^{n}\right) \frac{\partial}{\partial y}\left(D_{21}^{n} U_{x}^{n}\right)+\frac{\partial}{\partial y}\left(D_{22}^{n} U_{y}^{n}\right)+\frac{\partial}{\partial y}\left(D_{23}^{n} U_{z}^{n}\right)+ \\
\left.\frac{\partial}{\partial z}\left(D_{31}^{n} U_{x}^{n}\right)+\frac{\partial}{\partial z}\left(D_{32}^{n} U_{y}^{n}\right)+\frac{\partial}{\partial z}\left(D_{33}^{n} U_{z}^{n}\right)\right\}
\end{gathered}
$$

Where $U^{n}$ and $U^{n+1}$ are the filter outputs at sample $n \Delta s$ and $(n+1) \Delta s$, and $D^{n}$ is diffusion tensor.

Using the equations presented above, filtering is performed in the following steps:

1. Input seismic data are represented by $\mathrm{U}^{0}$.

2. Structure gradient tensor $J_{\rho}\left(\nabla U^{n}\right)$ for $U^{n}$ and scale $\rho$ is constructed using Equations 6 , 7 , and 8 .

$$
\begin{gathered}
J_{\rho}\left(\nabla U^{n}\right)=K_{\rho} * J_{0}=K_{\rho} *\left(U\left(\nabla U^{n}\right)^{T}\right) \\
K_{\rho}(\boldsymbol{r})=\left(2 \pi \rho^{2}\right)^{\frac{-3}{2}} \exp \left(\frac{|\boldsymbol{r}|^{2}}{\left(2 \rho^{2}\right)}\right) \\
|\boldsymbol{r}|^{2}=\left(x-x_{0}\right)^{2}+\left(y-y_{0}\right)^{2}+\left(z-z_{0}\right)^{2}
\end{gathered}
$$


3. Eigenvectors $\mathbf{V}_{1}, \mathbf{V}_{2}$, and $\mathbf{V}_{3}$ for $J_{\rho}\left(\nabla U^{n}\right)$ and eigenvalues $\mathrm{L}_{1}, \mathrm{~L}_{2}$, and $\mathrm{L}_{3}$ are calculated.

4. Using values from Step 3 and Equations 9 and 10 , the diffusion tensor $\mathrm{D}^{\mathrm{n}}$ is evaluated.

$$
\begin{gathered}
\left\{\begin{array}{c}
\vartheta_{1}=\alpha+(1-\alpha) \exp \left(\frac{-c}{\left(L_{1}-L_{2}\right)^{2 m}}\right) \\
\vartheta_{2}=\alpha \\
\vartheta_{3}=\alpha
\end{array}\right. \\
D=\left(v_{1} v_{2} v_{3}\right)\left|\begin{array}{ccc}
\vartheta_{1} & 0 & 0 \\
0 & \vartheta_{2} & 0 \\
0 & 0 & \vartheta_{3}
\end{array}\right|\left(v_{1} v_{2} v_{3}\right)^{T}=\left|\begin{array}{lll}
D_{11} & D_{12} & D_{13} \\
D_{21} & D_{22} & D_{23} \\
D_{31} & D_{32} & D_{33}
\end{array}\right|
\end{gathered}
$$

5. Using Equation 5, the value $\mathrm{U}^{\mathrm{n}+1}$ is calculated, until $\mathrm{n}=\mathrm{N}-1$.

6. The filtered signal is obtained as an output.

\section{Local geology}

The presented research was conducted on data from different parts of The Carpathian Foredeep (Fig. 1). 3D seismic data from different time periods were used. The main idea was to examine as many different stratigraphic levels as possible. In consequence - due to changing in stratigraphy - seismic data from different parts of the presented area have to be considered. Typical stratigraphy for this region consists of the oldest Precambrian complexes dated on the Neoproterozoic era. They are represented by strongly metamorphosed phyllites and meta-arqillites with different levels of tectonic involvement (dips over $60^{\circ}$ ) [17]. The higher Ordovician rocks are represented by grey-green, fine-grained, quartzite sandstones with glauconite, quartize conglomerates and crystal limestone $[18,19]$. The Silurian complex is represented by loamed shales with limestone and marl interbreeds. Their thickness is about 20-300 meters [20]. The Devonian complex is made of carbonate rocks in the upper and middle part and terrigenous sediments in the lower part. Lower Devonian rocks are mostly argillaceous, grey sandstones, red or green clays, and mottled mudrocks. The thickness of this complex is variable. Upper Devon rocks of this complex manifest as limestone and dolomite breccias slightly successioning into carbonate rocks. For the last type of the mentioned complex, we can include dolomite, limestone, and micro-crystalic dolomitic limestone.

Triassic rocks are divided on three different complexes, i.e. the lower, consisting of sandstone, the middle, consisting of limestone (sediment of sea environment), and the Kajper, consisting of sandstone and mudrock [21]. The oldest Jurassic complexes of the Carpathian range are observed from the Middle Jurassic (Dogger). They have been deposited in the depression of Triassic sediments. Rocks of Middle Jurassic are represented by clastic deposits with thick intrabeddings of marl [22]. The Upper Jurassic is made of limestone complexes that are deposited on Middle Jurassic rocks or Paleozoic rocks. A Biochermas series is present by regular lines connected to the upheaval of the sea bottom. Their maximum thickness could be over several hundred meters [23]. The seismic signal inside these structures is highly attenuated.

The Lower Cretaceous period is represented by sediments similar to Upper Jurassic; however, they have strong facial differentiation. Their special range in the considered area is limited to the area between Radomyśl, Jastrząbka Stara and Zagorzyce [24]. On the morphologically differentiated surface of the substrate, the autochthonous Miocene deposits are present. Their thickness varies from $200 \mathrm{~m}$ up to $1000 \mathrm{~m}$ in the presented area. The lower Miocene series is filled with the erosive unevenness of the substrate. They often outcrop on 
slopes of depressions. Over the Sarmat complex, there are Quaternary deposits represented by clay, gravel, and ice and river-transported sands. Their thickness is less than $60 \mathrm{~m}$ on the considered area [25].

The presented geological structure of the area of investigation, with its complex tectonic and stratigraphy, various sediments and facies, is definitely a challenge for seismic processing and interpretation.

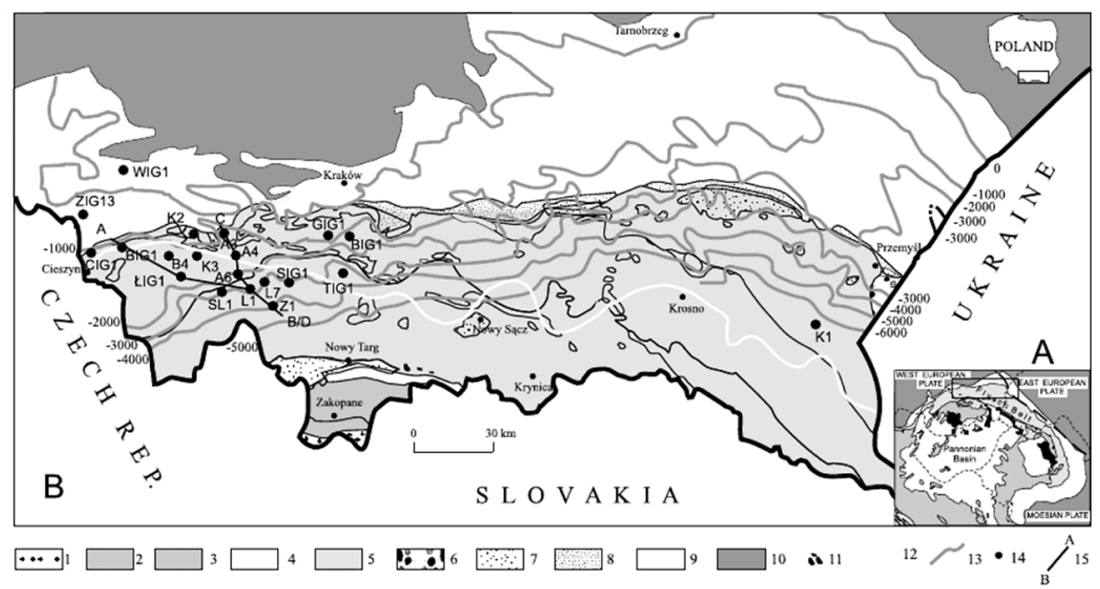

Fig. 1. Position of the Polish Carpathian Foredeep in the Carpathian -Pannonian Region. B. Sketchmap of the Polish Carpathians and their foredeep (after Oszczypko \& Oszczypko-Clowes [26]); 1 crystalline core of Tatra Mts., 2 - high and sub -Tatra units, 3 - Podhale Flysch, 4 - Pieniny Klippen Belt, 5 - Outer Carpathians, 6 - Stebnik Unit, 7 - Miocene deposits upon Carpathians, 8 - Zgłobice Unit, 9 -Miocene of the foredeep, 10 - Mesozoic and Palae-ozoic foreland deposits, 11 -andesites, 12 - northern extent of Lower Miocene, 13 - isobath of Miocene substratum, 14 - boreholes, 15 geological cross-section.

\section{Results of application in The Carpathian Foredeep}

In this paper, data from different parts of The Carpathian Foredeep were used. The quality of recorded seismic data was relatively good with a high signal to noise ratio; however, some horizons had been poorly preserved in processed sections. The decreasing quality of the seismic signal in the Jurassic, Cretaceous, and autochthonous Miocene sediments, which are considered as reservoirs in The Carpathian Foredeep, have been noticed [27, 28]. As shown in Fig. 2, Mark 1, the signal in Miocene sediments has low amplitude with a lot of discontinuities. At a lower part of presented section, below strong anhydrite reflection (Mark 2), Craterous and Jurassic rocks are present (Mark 3). As is typical for anhydrite horizons, the decrease in amplitude below them is visible. To improve the quality of presented seismic section, anisotropic diffusion filtering was applied. Figure 2A shows the results of this operation. Improvement is clearly visible. Horizons inside the Miocene sediment complex were properly recovered and their continuity is highly improved. Moreover, the positive effect of the algorithm is also visible in the Mesozoic part, where interpretational value of data was highly improved. 

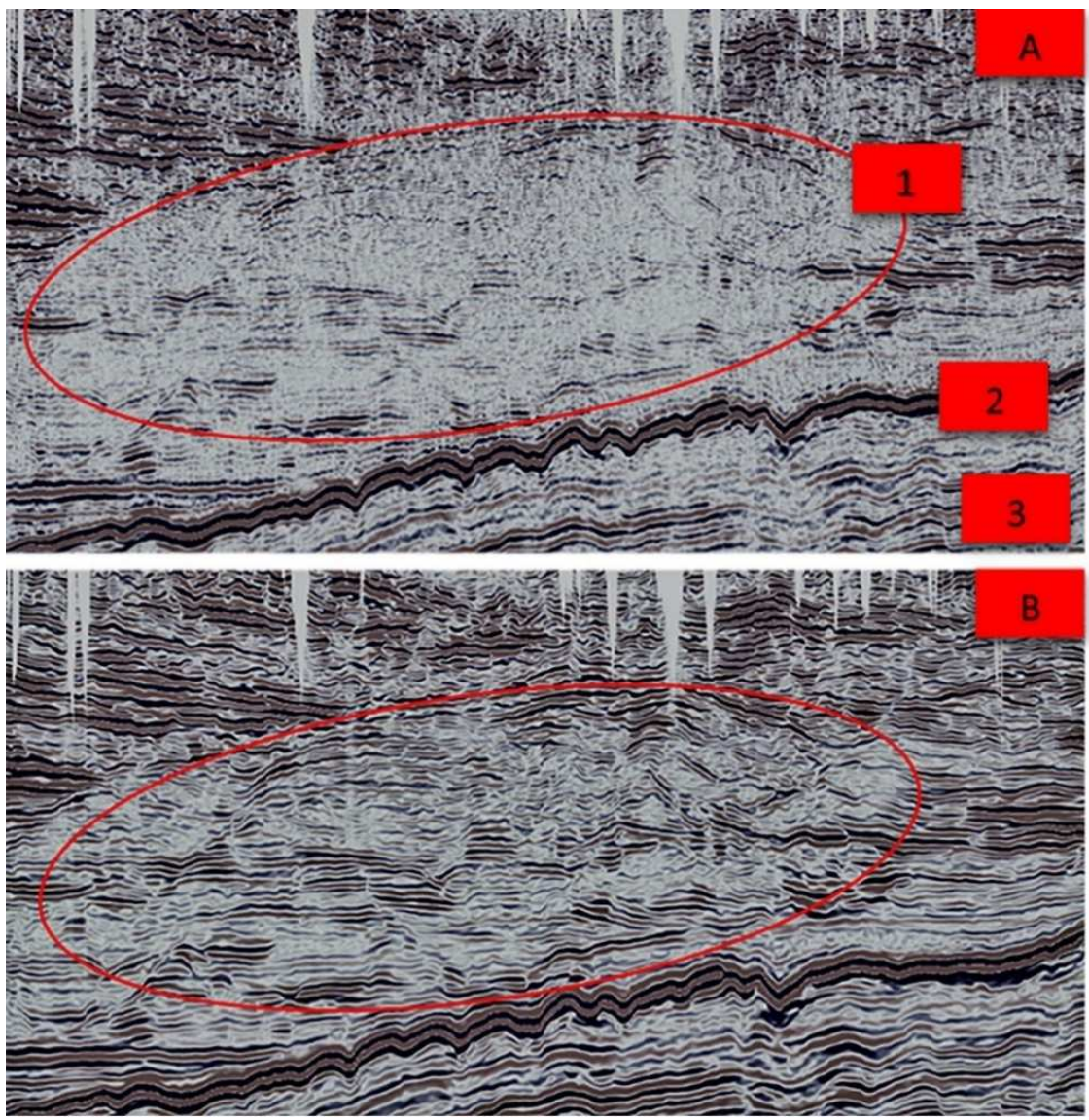

Fig. 2. A comparison of the seismic sections of 1 - Miocene, 2 - Anhydrite, 3 - Mesozoic sediments before (A) and after (B) filtering application.

Research shows that mudstones and claystone facies of Miocene sediments are gas reservoirs [4]. Due to lateral changes in reservoir facies, it is important to obtain more detailed images of the subsurface. It is extremely important to figure out the genesis of seismic anomalies on sections. Dim outs, the chaotic, and anomalous signal in a particular region could be considered hydrocarbon indicators. However, it is possible that the mentioned phenomena are not connected with the presence of hydrocarbons. The history of using DHI (Direct Hydrocarbon Indicator) in The Carpathian Foredeep in Poland between years 1994 and 2003 shows that $32 \%$ of wells drilled in locations chosen according to DHI interpretation were dry [4]. Seismic processing techniques that preserve the "true" signal characteristic are necessary for the proper interpretation stratigraphy and DHI in the case of decreasing number of dry wells in The Carpathian Foredeep. It is easily noticeable that the seismic signal in Miocene sediments (Fig. 2 Mark 1) has been strengthened after the application of anisotropic diffusion filtering, but there is an area of carbonated structures (Fig. 3, orange circle) in which the signal has not been strengthened. It is a highly expected effect. Bioherms are, next to other reef structures, important in the case of carbonate reservoirs, even though they could be more oil-wet then water-wet in character when compared to similarly aged sandstones [29]. Bioherms can be identified on the seismic section as almost a reflection free zones [30] or zones with chaotic signals. They usually occur on uphill sections (as seen on Fig. 3). The correlation of Jurassic horizons after filtering (Fig. 3A) is clearly better, but the signal in the bioherm section is still chaotic and weak. 
What is important relation between low and high amplitude parts of presented seismic sections is well preserved after anisotropic diffusion filtering. It is clearly visible that anisotropic diffusion filtering helps overcome problems that other structural filtering techniques do not. We obtained better structural information and preserved seismic anomalies that can indicate a hydrocarbon presence. Additionally, in Miocene sediments, the presented filtration helps to prevent the misinterpretation. An area in Fig. 2A, Section 1 without anisotropic diffusion filtering could be interpreted as a dim out. After applying anisotropy diffusion filtering, the signal is aligned over the entire area (Fig. 2B). The presented technique is independent of the observer, so it helps to obtain a more objective seismic image of the subsurface during the processing stage, which can be later properly interpreted.

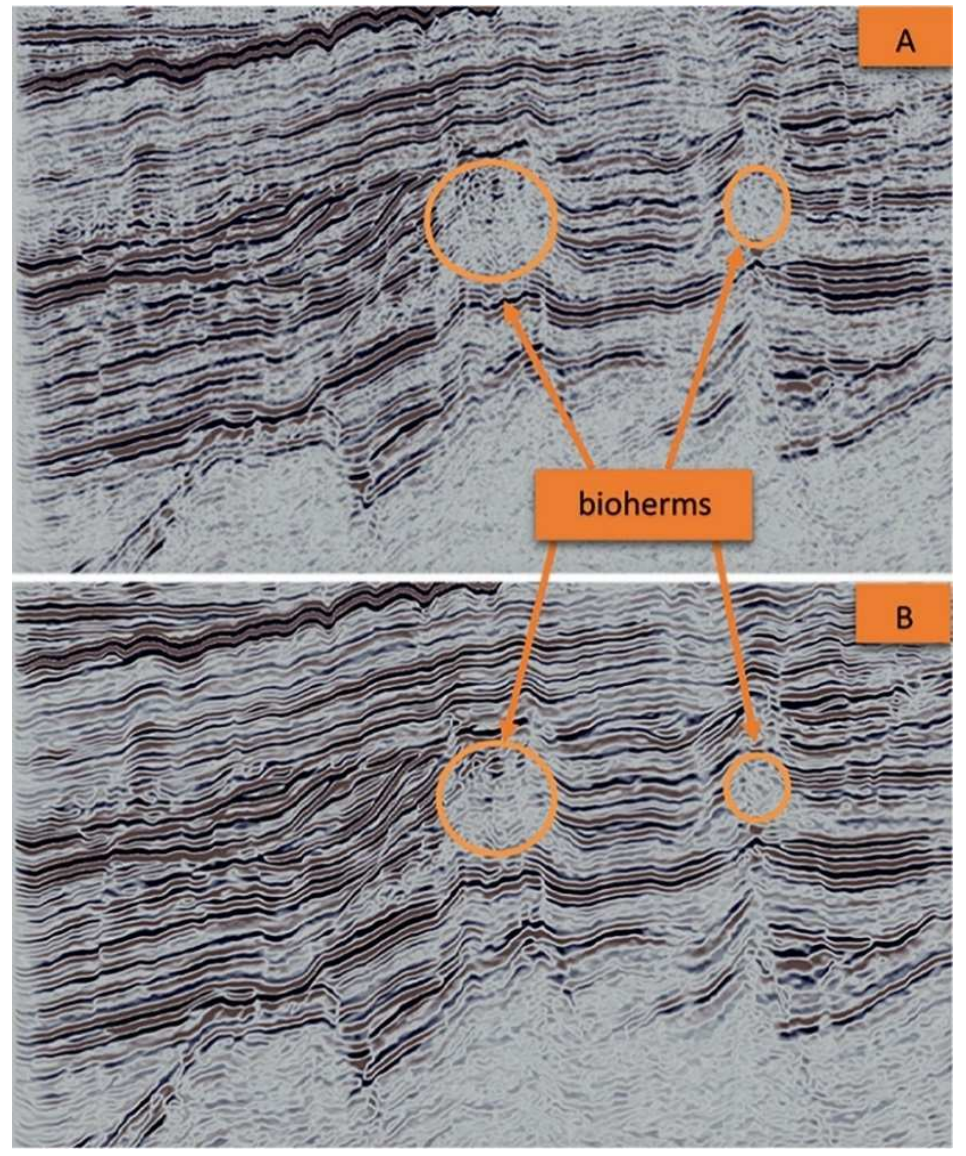

Fig. 3. A comparison of the seismic section of Mesozoic sediments before (A) and after (B) filtering application.

Another example of using the anisotropic diffusion algorithm comes from the region where Carpathian overlaps Miocene sediments. It is a very problematic region, because of the presence of dips. It causes problems with velocity analysis (because of significant lateral changes) and at later stages of time migration. In Fig. 4, the comparison of this region before and after filtering is presented. Dipping horizons have better correlation and are longer than their apparent image before filtration. Proper mapping of dips in the Carpathian range has always been a challenge for seismic processing. The ambiguous origin of problems should be resolved in the processing stage by using objective techniques (e.g., nonlinear anisotropic 
diffusion filtering). Only a proper image of subsurface can be correctly interpreted. We have to ensure that we strengthened true dips, and attenuated noise, migration artefacts, and other unwanted reflections during the processing stage (as shown in Fig. 4).

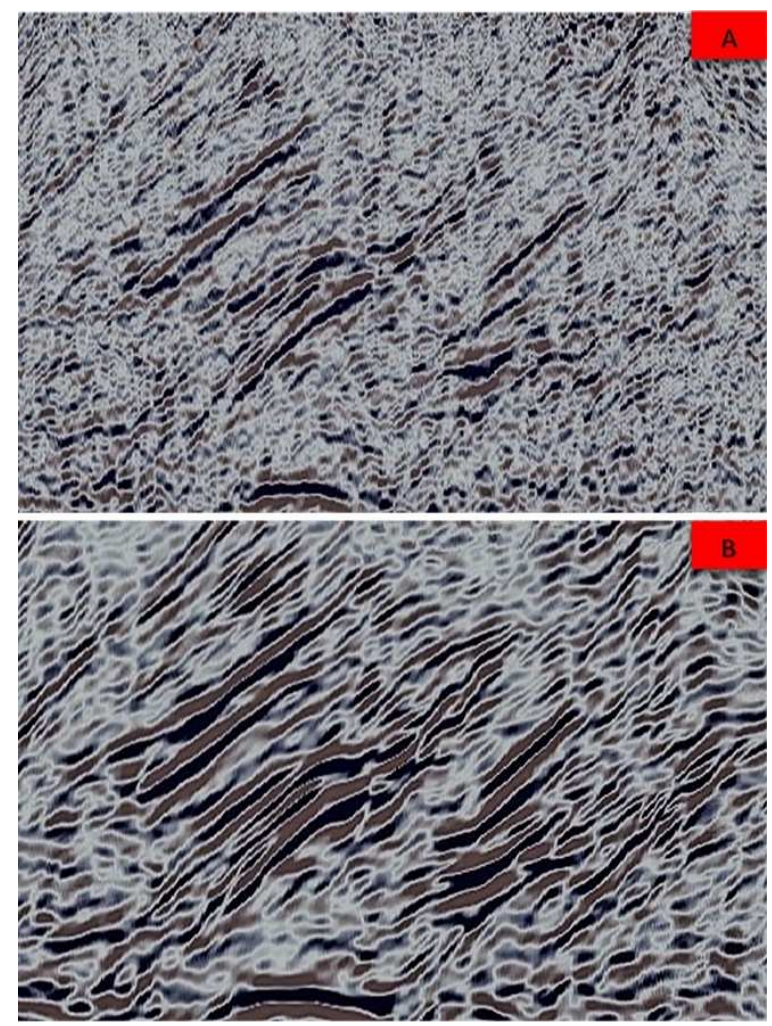

Fig. 4. A comparison of the seismic section of the Carpathian overlap before (A) and after (B) filtering application.

\section{Conclusion}

Presently, proper structural interpretation and the search for new hydrocarbons reservoirs require the use of precise techniques of geological structure imaging. The application of the digital image processing for enhancing 3D seismic surveys in areas where geological structures are very complicated and seismically "unfriendly" is very promising. The presented study shows the results of using a nonlinear anisotropic diffusion algorithm for post-stack processing of 3D seismic data collected in The Carpathian Foredeep region of southern Poland. Notably, the application of this algorithm provided a reliable seismic image of complicated geology, without any additional input from the interpreter.

It was shown that anisotropic diffusion can be used for advanced seismic signal processing. It allows for an improvement of seismic data quality and for more accurate interpretation by the recovery of a significant amount of structural information in the form of correlated seismic reflections. It is also a tool which allows searching for more subtle details of geological structures. According to the presented study, nonlinear anisotropic diffusion filtering is a powerful tool for the reliable reconstruction of the seismic image in the complicated geology region of The Carpathian Foredeep. It allowed proper structural interpretation and preserved seismic anomalies related to hydrocarbon reservoirs. 
This research was supported by AGH - University of Science and Technology, Faculty of Geology, Geophysics and Environmental Protection as a part of the statutory project No. 11.11.140.613

\section{References}

1. M. Myśliwiec et al., AAPG Memoir, 84, 391 (2006), DOI:10.1306/985613M843073

2. W. Moryc, Rozwój badan utworów miocenu w Karpatach Zachodnich na obszarze Bielsko - Kraków (Development of research on Western Carphatian Miocen deposits in the Bielsko-Kraków area), Geologia 31, 7-8 (2005) (in Polish)

3. L. Jankowski, J. Probulski, Rozwój tektoniczno-basenowy Karpat zewnętrznych na przykładzie budowy geologicznej złóż Grabownica, Strachocina i Łodyna oraz ich otoczenia (Tectonic and basinal evolution of the Outer Carpathians based on example of geological structure of the Grabownica, Strachocina and Lodyna hydrocarbon deposits), Geologia, 37, 556-583 (2011) (in Polish)

4. M. Myśliwiec, Poszukiwania złóż gazu ziemnego w osadach miocenu zapadliska przedkarpackiego na podstawie interpretacji anomalii sejsmicznych (Exploration for gas accumulations in the Miocene deposits of the Carpathian Foredeep using Direct Hydrocarbon Indicators), Przegląd Geologiczny, 52, 299-306 (2004) (in Polish)

5. S. Tlałka,73rd EAGE Conf. \& Exhib. incorp. SPE EUROPEC (2011) DOI: 10.3997/22144609.20149535

6. M. Cyz, M. Malinowski, M. Mulińska, SEG Technical Program Expanded Abstracts, 692-696 (2017), DOI:10.1190/segam2017-17789092.1

7. B. Papiernik, M. Krzysztofik, S. Franczak, Wstępne modele geologiczne miocenu autochtonicznego $w$ wybranych strefach $w$ pobliżu frontalnego nasunięcia karpackiego (Preliminary geological of autochthonous Miocene in the selected zones proximal to the Frontal Carphatian Overthrust), Cooperation of science and industry in hydrocarbon exploration and production, Conference magazine of the Oil and Gas Institute, Kraków, 209, 101-105, (2016) (in Polish)

8. W. Kubociński, Interakcyjna sektoryzacja i selektywne sumowanie kolekcji pelnego azymutu (Interactive sectoring and selective stacking of the 3D full azimuth directional gathers - the new tool to analyse structural image), Cooperation of science and industry in hydrocarbon exploration and production, Conference magazine of the Oil and Gas Institute, Kraków, 209, 193-196 (2016) (in Polish)

9. M. Zaręba, Zaawansowane metody zwiększania koherencji sygnału sejsmicznego (The use of advanced seismic techniques to enhance coherency of seismic signal), Cooperation of science and industry in hydrocarbon exploration and production, Conference magazine of the Oil and Gas Institute, Kraków, 209, 201-204 (2016) (in Polish)

10. J. Weickert, Anisotropic diffusion in image processing, Department of Computer Science, University of Copenhagen, Copenhagen, Denmark (1998)

11. M. Black, G. Sapiro, LECT NOTES COMPUT SC, 1682, 259-270 (2012) DOI: 10.1007/3-540-48236-9

12. K. Baddari, J. Ferahtia, T. Aifa, N. Djarfour, COMPUT GEOSCI, 37, 4, 456-463 (2011) DOI:10.1016/j.cageo.2010.09.009

13. H. Kowalski, W. Kubociński, Sejsmiczny obraz geologii: czasowy, gtębokościowy, a może dyfrakcyjny? (Seismic image of geology: time, depth, or diffractive?), Cooperation of science and industry in hydrocarbon exploration and production, Conference magazine of the Oil and Gas Institute, Kraków, 198, 247-251 (2014) (in Polish) 
14. O. Lavialle, S. Pop, Ch. Germain, M. Donias, S. Guillon, N. Keskes, Y. Berthoumieu, J APPL GEOPHYS, 61, 132-141 (2007) DOI: 10.1016/j.jappgeo.2006.06.002

15. E. Wang, G. Yan, L. Li, SEG Technical Program Expanded Abstracts, 1590-1594 (2013), DOI: 10.1190/segam2013-0564.1

16. J. Weickert, INT J COMPUT VISION, 31, 111-127 (1999) DOI: 10.1023/A:1008009714131

17. W. Moryc, M. Jachowicz, Utwory prekambryjskie w rejonie Bochnia-Tarnów-Dębica (Precambrian deposits in the Bochnia-Tarnów-Dębica area), Przegląd Geologiczny, 48, 601-606 (2000) (in Polish)

18. W. Moryc, Stratygrafia warstw w głębokim otworze Niwki 3 koło Dabrowy Tarnowskiej (Stratigraphy of the geological formations in the deep borehole Niwki 3 near Dabrowa Tarnowska), Geologia, 19, 87-106 (1974) (in Polish)

19. H. Tomczyk, Ordowik i sylur w podłożu Zapadliska Przedkarpackiego (Ordovician and Silurian in the basement of the Fore-Carpathian Depression), Rocznik Polskiego Towarzystwa Geologicznego, 33, 289-320 (1963) (in Polish)

20. M. Jachowicz, Mikroskamieniałości organiczne terenewu (kambr dolny) i póżnego ediakaru (neoproterozoik) okolic Krakowa (The Terreneuvian and late Ediacaran organic microfossils from Kraków area), Biuletyn Państwowego Instytutu Geologicznego, 459, 61-82 (2014) (in Polish)

21. H. Senkowiczowa, Wapień Muszlowy na poludniowym zboczu Gór Świętokrzyskich między Czarna Nidq a Chmielnikiem (The Muschelkalk on the southern Slope of the Święty Krzyż Mts. between Czarna Nida and Chmielnik), Biuletyn Instytutu Geologicznego, 122, 5-67 (1957) (in Polish)

22. W. Moryc, Budowa geologiczna podtoża miocenu w rejonie Kraków-Pilzno. Cz. 2. Perm i mezozoik (Geological structure of Miocene substratum in Kraków-Pilzno region. Part 2. The Permian and Mesozoic period), Nafta-Gaz, 62, 6, 263-282 (2006) (in Polish)

23. J. Gutowski, A. Urbaniec, Z. Złonkiewicz, L. Bobrek, B. Świetlik, P.Gliniak, Stratygrafia górnej jury i dolnej kredy środkowej części przedpola polskich Karpat (Upper Jurassic and lower Cretaceous of the middle polish Carpathian foreland), Biuletyn Państwego Instytutu Geologicznego, 426, 1-26 (2007) (in Polish)

24. A. Urbaniec, L. Borek, B. Świetlik, Litostratygrafia $i$ charakterystyka mikropaleontologiczna utworów kredy dolnej w środkowej części przedgórza Karpat (Lithostratigraphy and micropalaeontological characteristic of Lower Cretaceous strata in central part of the Carpathian Foreland), Przegląd Geologiczny. 58, 12, 11611175 (2010) (in Polish)

25. J. Karnkowski, Osady miocenu Zapadliska Przedkarpackiego (Miocene deposits of the Carpathian Foredeep), GEOL Q, 38, 3, 377-394 (1994) (in Polish)

26. N. Oszczypko, M. Oszczypko-Clowes, ACTA GEOL POL 53, 101-122 (2003)

27. M. Pawlewicz, Total Petroleum Systems of the North Carpathian Province of Poland, Ukraine, Czech Republic, and Austria, U.S. Geological Survey, Reston, Virginia (2006)

28. A. Shouket, J. Jarzyna, Reservoir properties and facies characterization from core data and well logging: autochthonous Miocene sediments in the Carpathian Foredeep case study, Geology, Geophysics \& Environment, 40, 4, 331-342 (2014)

29. P.C.H. Veeken, Seismic Stratigraphy and Depositional Facies Models 1st Edition, Academic Press, EAGE Publication, 313 (2013)

30. L. Buryakovsky, G. Chilingar, H. Rieke, S. Shin, Fundamentals of the Petrophysics of Oil and Gas Reservoirs, Wiley, USA, 47 (2012) 